\title{
A cyclized peptide derived from $\alpha$ fetoprotein inhibits the proliferation of ER-positive canine mammary cancer cells
}

\author{
CRISTIAN GABRIEL TORRES ${ }^{1}$, ANA MARÍA PINO ${ }^{2}$ and WALTER DANIEL SIERRALTA ${ }^{1}$ \\ ${ }^{1}$ Laboratorios de Nutrición y Regulación Metabólica, Sección Ultraestructuras, and ${ }^{2}$ de Biología Celular, \\ INTA-Universidad de Chile, Avenida Macul 5540, Santiago 7830489, Chile
}

Received December 5, 2008; Accepted January 26, 2009

DOI: 10.3892/or_00000367

\begin{abstract}
The effects of estradiol $\left(\mathrm{E}_{2}\right)$ and of an AFP-derived cyclized peptide $(\mathrm{cP})$ on the proliferation of primary cultures of cancer cells isolated from spontaneous canine mammary tumors were studied. The cellular response to $\mathrm{E}_{2}$ and $\mathrm{cP}$ was related to the expression of estradiol receptor (isoforms $\alpha$ and B). In ER-positive cells, $2 \mathrm{nM}$ estradiol increased cell proliferation and the phosphorylation of ERK1/2;2 $\mu \mathrm{g} / \mathrm{ml}$ $\mathrm{cP}$ inhibited all these effects. Estradiol also increased HER2 immunoreactivity in ER-positive cells, an effect that was reverted to its basal values by $\mathrm{cP}$. Estradiol stimulated in these cells the release of MMP2 and MMP9 and the shedding of HB-EGF, effects that the cP did not affect. ER-negative cells were refractory to estradiol or $\mathrm{cP}$. All canine mammary tumor cells in culture responded to treatments analogously to human mammary cancer cells. Our results support the proposal of $\mathrm{cP}$ as a new, potentially effective therapeutic agent for the management of mammary cancer.
\end{abstract}

\section{Introduction}

Estrogens play an important role in the normal development and occurrence of neoplasms in the mammary gland. 17ßestradiol $\left(E_{2}\right)$, the most potent natural estrogen, is necessary for growth and differentiation of the gland (1) and participates in the initiation and evolution of breast cancer (2). It is widely accepted that the biological activities of estradiol are mediated by an estrogen receptor (ER), transcription factor that upon association with the hormone form dimers and activate the transcription of specific genes containing the estrogen response elements. In addition, estradiol bound to cytoplasmic or membrane-associated receptors promotes signaling pathways that crosstalk with those of other cell growth factors, for instance, members of the epidermal- (EGFR) and the insulinlike growth factor receptor (IGFR) families, both activating the

Correspondence to: Dr Walter D. Sierralta, Laboratorio de Nutrición y Regulación Metabólica, Sección Ultraestructuras, INTA-Universidad de Chile, Avenida Macul 5540, Santiago 7830489, Chile

E-mail: wsierra@uchile.cl

Key words: canine mammary cancer cells, estradiol, $\alpha$ fetoprotein, cyclized peptide, HER2/neu kinase cascades (reviewed in ref. 3). The acquired resistance to endocrine therapies of some mammary tumors treated with inhibitors of ER, is considered to result from strengthening of this signaling crosstalk (4).

Few years ago researchers at the Albany Medical College, synthesized a cyclic oligopeptide (cP) that inhibited the growth of estradiol-dependent mammary tumors xenoimplanted into severely immuno-deficient mice $(5,6)$. The cyclized peptide contains the minimal active amino acid sequence from $\alpha$ fetoprotein (AFP), exhibits a prolonged shelf life and is devoided of toxicity (6). Consecutive studies by the group at Albany demonstrated that the oral administration of the $\mathrm{cP}$ to rats delayed the initiation and growth of mammary tumors induced by administration of the $\mathrm{N}$-methyl-N-nitrosourea carcinogen $(7,8)$. Using estrogen-sensitive human mammary cancer cells, we recently demonstrated that $\mathrm{cP}$ hinders the crosstalk between EGFR2 (HER2) and ER, decreasing the levels of phosphorylated extra-cellular kinases 1 and 2 (phospho-ERK1/2) and repressing the estradiol-stimulated cell proliferation $(9,10)$. In addition, $\mathrm{cP}$ inhibited the effects of both EGF and transforming growth factor $\alpha(\mathrm{TGF} \alpha)$ on cell proliferation; the antiproliferative activity of the $\mathrm{cP}$ was independent of the presence of serum in the cultures (9).

In female dogs, mammary cancer is the prevalent form of neoplasia, accounting for over $30 \%$ of all cancers $(11,12)$. In these animals, estrogens and progestins act synergistically, promoting growth and differentiation of the mammary gland and the establishment and progression of cancer; therefore, a large number of canine mammary tumors retain steroiddependency (13). The spontaneous canine mammary tumors usually receive only surgical treatment, in few cases the animals are therapeutically irradiated and occasionally they are treated with (anti-)hormones. The assessment of ER and $\mathrm{PR}$ in canine mammary biopsies is seldom used for the prognosis of cancer, explaining in part the scarce application of endocrine therapy in these animals (14). Interestingly, although canine and human $\alpha$ fetoprotein protein sequences differ slightly, the short domain containing the antiproliferative activity is highly conserved (15). Therefore, anti-proliferative effect of the $\mathrm{cP}$ on cell growth of ERpositive canine mammary tumors could be anticipated.

The aim of this study was to investigate the effect of $\mathrm{cP}$ on estradiol- and EGF-dependent proliferation of canine mammary tumor cells in primary culture. Results show 
increased cell proliferation of ER-positive tumor cells under estradiol stimulation, while the $\mathrm{cP}$ significantly inhibited this effect; neither estradiol nor the $\mathrm{cP}$ affected cell growth of ER-deprived cells. Also, in estradiol-responsive canine cancer cells, the cP inhibited EGF-stimulated cell propagation. Increased cell proliferation by these mitogens was related to the phosphorylation of ERK1/2 induced by HER2/neu activation, and it was reduced to basal rates in the presence of cP. ER-negative cells did not respond to estradiol, EGF nor to $\mathrm{cP}$, as has been observed in human MBA-MD-231 cells (10). The results presented herein add to those endorsing the $\mathrm{cP}$ as a potentially effective therapeutic agent to fight mammary cancer.

\section{Materials and methods}

Materials. The AFP-derived nonapeptide cyclo (EKTOVNOGN) (where $\mathrm{O}$ is hydroxyproline) and the control scrambled peptide were generously supplied by the Professors H.I. Jacobson, T. Andersen and J. Bennett, Albany Medical College, Albany, NJ, USA.

Tissue culture materials were obtained from NalgeNunc (Rochester, NY, USA), PVDF membranes and Precision Plus Protein Standards were purchased from BioRad Laboratories (Hercules, CA, USA). Recombinant human epidermal growth factor (rhEGF) (Cat GF001) was obtained from Chemicon International, Inc. (Temecula, CA, USA). Protease inhibitor cocktail III and estradiol were purchased from Calbiochem, EMD Biosciences (La Jolla, CA, USA); most other chemicals used in this study were provided by Sigma-Aldrich (St. Louis, MO, USA).

Antibodies: rabbit anti-ER $\alpha$ antibody (sc-543), rabbit anti-ERß antibody (sc-8974), rabbit anti-HER2 antibody (sc284), goat anti-HB-EGF antibody (sc-1414), rabbit anti-ERK polyclonal antibody (sc-154), mouse monoclonal anti-CK14 antibody (sc-23878) and FITC-conjugated goat anti-mouse IgG (sc-2010) were purchased from Santa Cruz Biotechnology, Inc. (Santa Cruz, CA, USA). Mouse antiepithelial specific antigen (ESA) monoclonal antibody (E6011), peroxidase-conjugated goat anti-mouse IgG (A4416) and peroxidase-conjugated goat anti-rabbit IgG (A6667) were obtained from Sigma-Aldrich. Rabbit antiMAP kinase (M2360-02A, specifically recognizing ERKs p44, p42, phosphorylated in Thr202, Tyr204) was supplied by United States Biological (Swampscott, MA, USA). Alexa Fluor 488 conjugated donkey anti-rabbit IgG (A21206) and Alexa Fluor 594-conjugated goat anti-rabbit IgG were purchased from Molecular Probes-Invitrogen Corp. (Carlsbad, CA, USA). The OmniTag Plus universal streptavidin/biotin peroxidase kit (Cat.No. 405150) was obtained from Thermo Shandon (Pittsburgh, PA, USA).

Tumor samples. Tissue samples were obtained in the course of surgeries at the Clinic of the Veterinary School of University of Chile. Samples from spontaneous tumors of bitches from diverse breeds and ages were obtained from animals diagnosed, anesthesized, and treated according to the animal welfare rules of the Ethics Committee from the Veterinary School. A small piece of the tumor tissue was plunged in buffered $4 \%$ paraformaldehyde, subsequently dehydrated and included in paraffin; afterwards, sections from the blocks were cut, stained with hematoxylin and eosin (H\&E) and inspected for histopathological diagnosis. On the basis of histology, the tumors were classified according to the WHO standards for canine and feline mammary neoplasies (16). Another sample of tissue (roughly $1 \mathrm{~cm}^{3}$ ) was dissected and suspended in DMEM/F12 medium supplemented with $10 \%$ fetal bovine serum and antibiotics and used to isolate cells.

Immunohistochemistry. The expression of ER $\alpha$ and ERß proteins in tumors was analyzed by immunohistochemistry in de-waxed sections from the same blocks used for $\mathrm{H} \& \mathrm{E}$ staining. To retrieve the antigens, the slides containing sections of tumor samples in $10 \mathrm{mM}$ citrate $\mathrm{pH} 6.0$ buffer were boiled ( 3 times for $5 \mathrm{~min}$ ) in an EMS Precision Pulsed microweaveoven. After cooling-down, the sections were treated with $1 \%$ glycine, blocked with 5\% BSA in phosphate-buffered saline and incubated with appropriate dilutions of the respective primary antibodies. After several washes, the samples were incubated sequentially with biotinylated secondary antibodies and streptavidin-conjugated peroxidase (OmniTags Plus kit), following the manufacturer's instructions; the immunostaining was developed with $\mathrm{DAB}$ and $0.06 \%$ hydrogen peroxide in buffer. After exhaustive rinses, the sections were counterstained with Mayer hematoxylin, dehydrated with alcohol and xylenes and mounted with Entellan. Sections of canine uteri and ovary treated as described above served as positive controls for ER $\alpha$ and $\beta$, respectively. For the negative controls, either non-immune rabbit IgG or $2 \%$ BSA replaced the primary antibody solutions. The tumors were classified on the basis of the percentage of stained cells in the sections, as follows: -, none or $<5 \%$ of the cells stained; + , from 5 to $19 \%$ of the cells stained; ++, from 20 to $59 \%$ of the cells stained.

Primary cell cultures. All procedures were done under sterile conditions at the cell culture laboratory: the tissue was carefully minced and treated overnight with $0.02 \%$ collagenase (type I) in DMEM/F12 supplemented with fetal bovine serum and antibiotics at $37^{\circ} \mathrm{C}$. Then, the cell suspension was filtered through nylon gauze $(80-\mu \mathrm{m}$ pore size) and cells were sedimented at $184 \mathrm{x} \mathrm{g}$ for $10 \mathrm{~min}$. The sediment was suspended in DMEM/ F12 containing $10 \%$ fetal bovine serum and antibiotics; cells were seeded and further treated as indicated below.

Proliferation studies. Cells (approximately 20,000 cells $/ \mathrm{cm}^{2}$ ), were seeded and allowed to attach for $24 \mathrm{~h}$ in medium containing $10 \%$ fetal bovine serum, then media and nonadherent cells were removed. The attached cells were washed and further incubated for various periods in medium containing $5 \%$ charcoal-treated calf serum (CTCS) and either $2 \mathrm{nM}$ estradiol, or $5 \mathrm{ng}$ rh EGF, in the absence or presence of $2 \mu \mathrm{g} / \mathrm{ml}$ $\mathrm{cP}$, media were renewed every $48 \mathrm{~h}$. In some experiments $100 \mathrm{nM}$ tamoxifen was added to samples containing $2 \mathrm{nM}$ estradiol. Control cells were incubated in CTCS medium, containing or not $2 \mu \mathrm{g} / \mathrm{ml}$ of a control, scrambled peptide. After treatments, cells were washed with phosphate-buffered saline (PBS), detached (0.25\% trypsin in $0.2 \mathrm{mM}$ EDTA), resuspended in PBS, counted and assessed for viability (trypan blue). All experiments were done in triplicate and repeated at least twice. 
Table I. Characteristics of donor animals and mammary tumors used to originate primary cell cultures.

\begin{tabular}{|c|c|c|c|c|c|c|}
\hline Case & $\begin{array}{l}\text { Reproductive } \\
\text { condition }\end{array}$ & Age (years) & WHO clinical staging & $\begin{array}{c}\text { Histological } \\
\text { diagnostic }\end{array}$ & Grade & $\begin{array}{l}\text { Tissue ER } \alpha \\
\text { expression }\end{array}$ \\
\hline
\end{tabular}

\begin{tabular}{|c|c|c|c|c|c|c|c|}
\hline CMTC 1 & Intact & 7 & III & SPA & I & + & + \\
\hline CMTC 2 & Intact & 9.5 & I & CPA & II & - & - \\
\hline СМТC 3 & Intact & 11 & II & $\mathrm{CC}$ & I & + & + \\
\hline СMTC 4 & Intact & 9 & I & $\mathrm{CC}$ & I & + & + \\
\hline СMTC 5 & Intact & 7 & II & SPA & I & + & + \\
\hline СMTC 6 & Intact & 8 & I & MBT & - & + & + \\
\hline СMTC 7 & Ovex & 10 & III & CTA & II & + & + \\
\hline СМТC 8 & Intact & 12 & IV & $\mathrm{FCC}$ & I & - & - \\
\hline СMTC 9 & Intact & 9 & I & $\mathrm{CC}$ & I & + & + \\
\hline СМТC 10 & Intact & 11 & IV & CPA & II & - & - \\
\hline СМТC 11 & Intact & 10 & I & SPA & II & - & - \\
\hline СMTC 12 & Ovex & 7 & I & $\mathrm{SC}$ & II & - & - \\
\hline СМТC 13 & Intact & 9 & II & $\mathrm{SC}$ & II & - & - \\
\hline СМТC 14 & Intact & 9 & I & MBT & - & + & + \\
\hline
\end{tabular}

SPA, simple papillar adenocarcinoma; CPA, complex papillar adenocarcinoma; CC, complex carcinoma; MBT, mixed benign tumor; CTA, complex tubullar adenocarcinoma; FCC, fused cell carcinoma; SC, solid carcinoma.

Immunofluorescence studies. The expression of ER $\alpha, \mathrm{ER} \beta$, HER2/neu, CK14 and ESA in cultured cells was analyzed by indirect immunofluorescence in mammary tumor cells grown on sterile coverglasses. After specified treatments, the cells were fixed (methanol, $20 \mathrm{~min}$ at $-20^{\circ} \mathrm{C}$ ), rinsed (PBS containing $2 \% \mathrm{BSA}$ ) and incubated for $1 \mathrm{~h}$ at RT with the primary antibodies diluted with PBS containing $2 \%$ BSA. (The dilutions used were: ER $\alpha$, 25-fold; ERß, 100-fold; HER2/neu, 75-fold; CK14, 30-fold and ESA 10-fold, respectively). After extensive washes (PBS containing 2\% BSA), cells were incubated with the appropriate fluorochrome-labeled secondary antibodies and the nuclei counterstained with Hoechst 33240. Finally, the cells were washed, mounted and viewed with a Zeiss Axiophot epifluorescence microscope fitted with a color CCD camera. In all experiments, the images were obtained under fixed settings of illumination, exposure times and camera gain. In few experiments, the samples were analyzed in a confocal Zeiss microscope model LSM 510 META.

Apoptosis studies. Cells $\left(20,000\right.$ cells $\left./ \mathrm{cm}^{2}\right)$ were seeded in B25 bottles; after cell attachment the cells were serum deprived for $24 \mathrm{~h}$. Then, cells were treated with medium containing or not $2 \mathrm{nM}$ estradiol, in the absence/presence of $2 \mu \mathrm{g} / \mathrm{ml} \mathrm{cP}$. At defined time periods, cells were released and aliquots were labeled with propidium iodide (PI, $10 \mathrm{mg} / \mathrm{ml}$ ), treated with RNAse A $(300 \mu \mathrm{g} / \mathrm{ml})$ and analyzed for DNA content using using a FACScalibur (Becton-Dickinson, CA, USA) with the ModFit LT ${ }^{\mathrm{TM}}$ software (Becton-Dickinson).

Western blot analysis. For total cell protein extraction, cells were sonicated in $62.5 \mathrm{mM}$ Tris, $\mathrm{pH} 6.8$ containing 2\% SDS, $50 \mathrm{mM}$ DTT, $10 \%$ glycerol and $0.01 \%$ bromophenol blue. For electrophoresis, 10-20 $\mu \mathrm{g}$ protein samples were incubated for $5 \mathrm{~min}$ at $95^{\circ} \mathrm{C}$ and loaded in $10 \%$ polyacrylamide gels.
Electrophoresis was carried out at $100 \mathrm{~V}$ using BioRad's Miniprotean chambers at RT. Bands were electrotransferred onto PVDF membranes, immunodetection was done by using the appropriate primary antibodies and peroxidase-labeled secondary antibodies and visualized by enhanced chemiluminescence (Renaissance Western Blot Chemiluminiscence kit from Perkin-Elmer, Boston, MA, USA). Phosphorylated ERK1/2 proteins were detected with the specific anti-phospho antibody and the rabbit antibody-antigen complexes tagged as indicated above. Relative levels of total ERK1/2 protein in each sample were determined by stripping the phosphospecific ERK1/2 antibodies from the membrane and reprobing with antibodies to non-phosphorylated ERK1/2. The immunoblot bands were analyzed with NIH Image J software.

Gelatin zymography. Matrix metalloproteinase (MMP) activities secreted into the culture medium by the tumor cells were analyzed by gel electrophoresis. Cells were incubated for $48 \mathrm{~h}$ in medium with $5 \%$ charcoal-treated calf-serum and then incubated for different periods with $2 \mathrm{nM}$ estradiol in the presence or absence of $2 \mu \mathrm{g} / \mathrm{ml} \mathrm{cP}$. The cell medium was removed, mixed with two volumes of SDS sample buffer $(0.125 \mathrm{M}$ Tris- $\mathrm{HCl}$, pH 6.8 containing $10 \%$ SDS, $8 \%$ sucrose, and $0.05 \%$ bromophenol blue), incubated for $30 \mathrm{~min}$ at $25^{\circ} \mathrm{C}$ and applied on $7.5 \%$ polyacrylamide copolymerized with $0.1 \%$ gelatin. The electrophoresis was performed as indicated before. After the run, the gels were washed three times, 20 min each, with $2.5 \%$ Triton $\mathrm{X}-100$ at room temperature and then incubated for $10 \mathrm{~h}$ at $37^{\circ} \mathrm{C}$ in $50 \mathrm{mM}$ tris $\mathrm{pH} 7.4$ containing $5 \mathrm{mM} \mathrm{CaCl}_{2}$ and $0.5 \mathrm{mM}$ $\mathrm{NaN}_{3}$. The gel was stained with $0.5 \%$ Coomassie blue and destained in acetic acid/methanol solution.

Statistical analyses. The Anova Kruskal Wallis test was used to evaluate differences between samples and the respective 
Table II. Characteristics of the canine mammary tumor cells in primary culture.

\begin{tabular}{|c|c|c|c|c|c|}
\hline \multirow[t]{2}{*}{ Case } & \multirow[t]{2}{*}{ Ratio ESA/CK14 } & \multicolumn{2}{|c|}{ Immunoreactivity of } & \multirow[t]{2}{*}{ Proliferative $\mathrm{E}_{2}$-effect } & \multirow[t]{2}{*}{ Inhibitory cP-effect } \\
\hline & & $\mathrm{ER} \alpha$ & $\mathrm{ER} ß$ & & \\
\hline CMTC 1 & $90 / 10$ & + & + & + & + \\
\hline СMTC 2 & $70 / 30$ & - & - & - & - \\
\hline СMTC 3 & $75 / 25$ & + & + & + & + \\
\hline CMTC4 & $70 / 30$ & + & + & + & + \\
\hline СМТC 5 & $80 / 20$ & + & + & + & + \\
\hline СМТС 6 & $65 / 35$ & + & + & + & + \\
\hline СMTC 7 & $75 / 25$ & + & - & + & + \\
\hline СМТС 8 & $30 / 70$ & - & - & - & - \\
\hline СМТС 9 & $75 / 25$ & ++ & ++ & + & + \\
\hline СMTC 10 & $70 / 30$ & - & - & \pm & \pm \\
\hline СMTC 11 & $85 / 15$ & - & - & - & - \\
\hline СMTC 12 & $90 / 10$ & - & - & - & - \\
\hline CMTC 13 & $85 / 15$ & - & - & - & - \\
\hline CMTC 14 & $70 / 30$ & ++ & + & + & + \\
\hline
\end{tabular}

Ratio ESA/CK14, proportion between the percentages of ESA+ and CK14+ cells counted in 10 inspected fields.

A

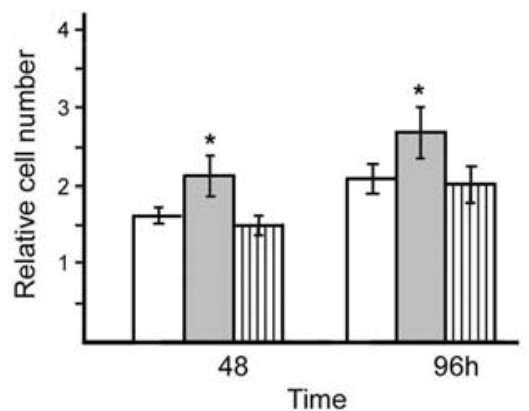

B

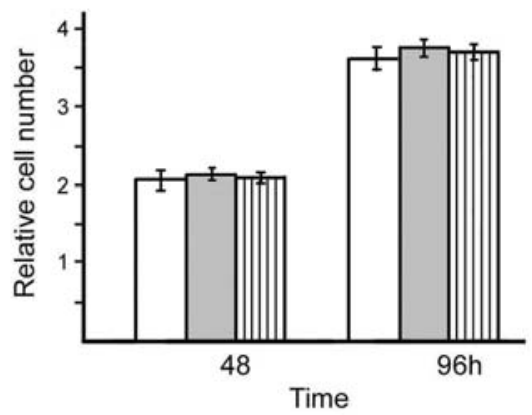

Figure 1. Actions of estradiol and the cyclo-peptide on canine mammary tumor cell proliferation. Effect of estradiol and cP on responsive CMT 9 tumor cells, (A) and on non-responsive CMT 11 tumor cells, (B) in primary cultures. Cells incubated in the absence (empty bars), or in the presence (grey bars) of 2 nM $\mathrm{E}_{2}$, or in the presence of $2 \mathrm{nM} \mathrm{E}$ plus $2 \mu \mathrm{g} / \mathrm{ml} \mathrm{cP}$ (hatched bars), as indicated in Materials and methods. Cell proliferation was expressed as the relative number compared with initial cell number $\left(20,700\right.$ cells $\left./ \mathrm{cm}^{2}\right)$. Values are mean $\pm \mathrm{SD}$ of 3 experiments in triplicate. ${ }^{*} \mathrm{p}<0.05$ compared with control or $\mathrm{cP}+\mathrm{E}_{2}$.

controls; $\mathrm{p}<0.05$ was considered significant. Data were analyzed with SyStat for Windows, release 6, SyS Inc. San José, CA, USA.

\section{Results}

Characteristics identified in the mammary tumors used for establishing defined primary cell cultures are summarized in Table I. All tumors were classified into six different types by histological analysis; six tumors did not show immunoreactivity for ER $\alpha$ or $\mathrm{ER} \beta$, while the other neoplasias showed immunoreactivity for one or both estradiol receptor isoforms. All subsequent studies were done in primary culture obtained from 14 different cell strains. General properties of these canine mammary tumor cells are summarized in Table II. As indicated by the ESA to CK14 immunolabeling ratios, the cell cultures had a prevalent epithelial character, except for CMTC8. Eight primary cell cultures were ER-positive, retaining the ER isoform present in the original tissue, while the six cell lines originated from ER-negative tumors expressed no ER isoform. The table also shows the proliferative effect of $2 \mathrm{nM}$ estradiol on all ER-positive primary cultures, which was reduced to basal values in the presence of $2 \mu \mathrm{g} / \mathrm{ml} \mathrm{cP}$. ER-negative tumor cells did not show response to estradiol treatment, nor were they affected by the presence of the $\mathrm{cP}$ in the culture medium.

The effects of estradiol and $\mathrm{cP}$ on the proliferation of canine mammary cells are exemplified by two individual cell strains, CMTC 9 and CMTC 11, representing ER-positive and ER-negative cells, respectively. Fig. 1A demonstrates a clear positive effect of $2 \mathrm{nM} \mathrm{E}$ on cell growth, at both 48 and $96 \mathrm{~h}$ of treatment; this effect was abolished by the presence of $2 \mu \mathrm{g} / \mathrm{ml} \mathrm{cP}$ during treatment. In contrast, ER-negative cells proliferated rather faster than ER-positive cells, but neither estradiol nor $\mathrm{cP}$ exerted an effect on cell proliferation at the time-points studied (Fig. 1B). The mean proliferative 


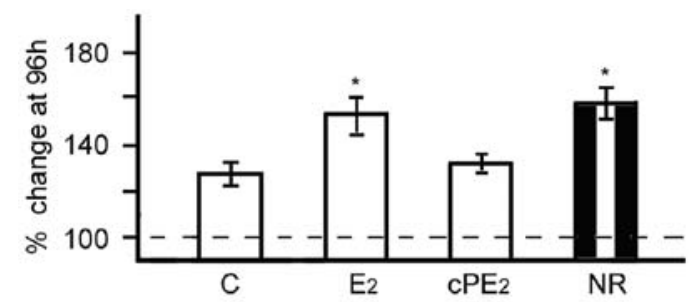

Figure 2. Effect of $\mathrm{E}_{2}$ and $\mathrm{cP}$ on canine mammary tumor cell proliferation. The histogram depicts the percentage of change in cells as compared to initial cell number. C, non-stimulated cells, exhibiting cell basal growth $(n=14) ; E_{2}$, cells exposed to $2 \mathrm{nM} \mathrm{E}_{2}(\mathrm{n}=8)$; cPE2, cells exposed to $2 \mathrm{nM} \mathrm{E}_{2}$ and $2 \mu \mathrm{g} / \mathrm{ml} \mathrm{cP}(\mathrm{n}=8)$; NR, cells non-responding to $\mathrm{E}_{2}$ nor to $\mathrm{cP}(\mathrm{n}=6)$. Results are the mean \pm SEM from independent experiments run in triplicate; *p $<0.05$ compared to $\mathrm{C}$ value.

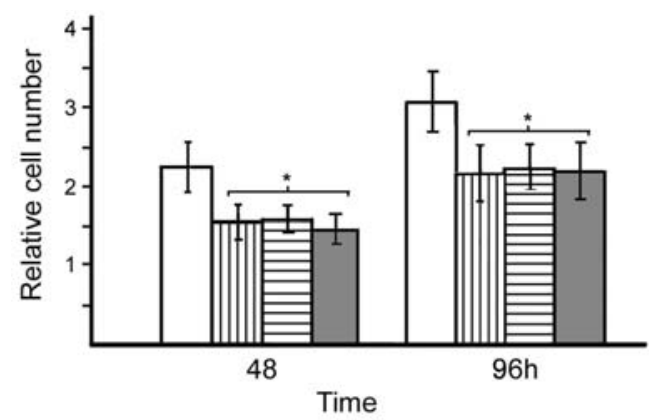

Figure 3. Effect of $\mathrm{cP}$ and tamoxifen on estradiol-stimulated canine mammary tumor cell propagation. CMT 6 cells were incubated in the presence of $2 \mathrm{nM} \mathrm{E}_{2}$ alone (empty bars), or $2 \mathrm{nM} \mathrm{E}_{2}$ plus $2 \mu \mathrm{g} / \mathrm{ml} \mathrm{cP}$ (vertically hatched bars), or in the presence of $\mathrm{E}_{2}$ plus $100 \mathrm{nM}$ tamoxifen (horizontally hatched bars), or in the presence of $2 \mathrm{nM} \mathrm{E}_{2}$ plus $2 \mu \mathrm{g} / \mathrm{ml} \mathrm{cP}$ and $100 \mathrm{nM}$ tamoxifen (grey bars). The proliferation rates were expressed as a relative numbers, calculated in relation to the initial cell numbers $\left(21,700 \mathrm{cells} / \mathrm{cm}^{2}\right)$. Values are mean \pm SD of 3 experiments in triplicate. ${ }^{*} \mathrm{p}<0.05$, as compared to control.

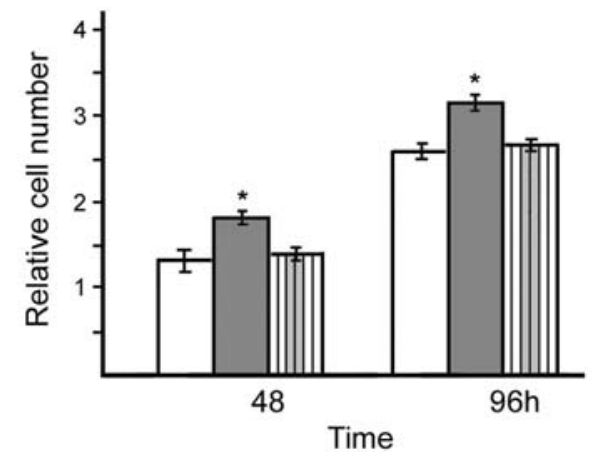

Figure 4. Effect of EGF on canine mammary tumor cells proliferation. CMT 9 cells were incubated in culture medium alone (empty bars), or with $5 \mathrm{ng} / \mathrm{ml} \mathrm{rh}$ EGF (grey bars), or in the presence of $5 \mathrm{ng} / \mathrm{ml} \mathrm{rh} \mathrm{EGF} \mathrm{plus} 2 \mu \mathrm{g} / \mathrm{ml} \mathrm{cP}$ (vertically hatched bars). Results are expressed as relative cell number, as compared to cell initial number $\left(20,400\right.$ cells $\left./ \mathrm{cm}^{2}\right)$. Values are mean \pm SD of 3 experiments in triplicate. ${ }^{*} \mathrm{p}<0.05$ compared to control value.

response of all cell samples at $96 \mathrm{~h}$, is summarized in Fig. 2; the mean cell growth under $2 \mathrm{nM}$ estradiol appears similar in both ER-positive and ER-negative cultures, however cell growth was inhibited by the presence of $2 \mu \mathrm{g} / \mathrm{ml} \mathrm{cP}$ during treatment only in ER-positive cultures.
A

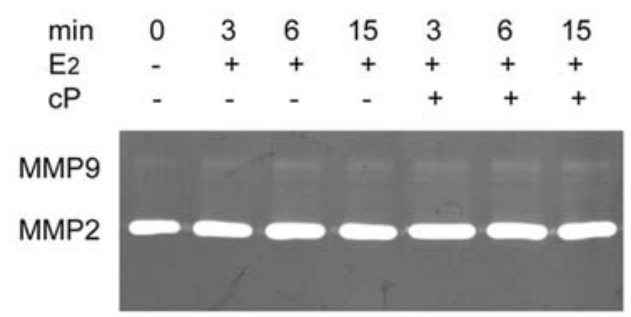

$\mathrm{B}$

$\begin{array}{llllllll}\min & 0 & 3 & 6 & 15 & 3 & 6 & 15 \\ \mathrm{E} 2 & - & + & + & + & + & + & + \\ \mathrm{CP} & - & - & - & - & + & + & +\end{array}$

HB-EGF

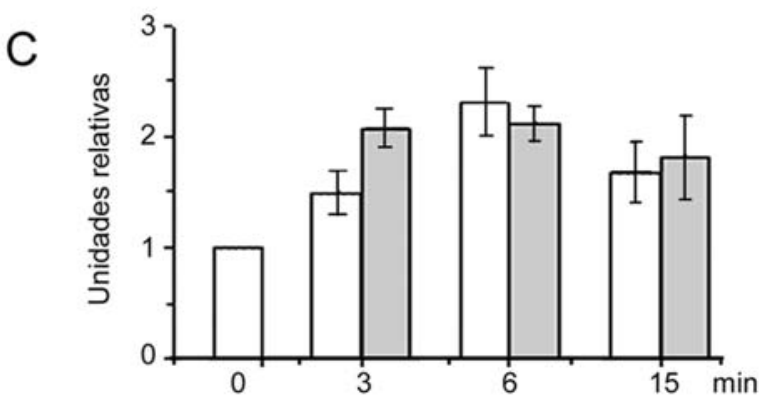

Figure 5. MMP activity and shedding of HB-EGF upon $\mathrm{E}_{2}$ stimulation. MMP2 and MMP9 activity detected by zymography of culture media from CMT 9 cells. Cells were incubated with $2 \mathrm{nM} \mathrm{E}_{2}$ in the presence or absence of $2 \mu \mathrm{g} / \mathrm{ml} \mathrm{cP}$ (A). Western blotting for HB-EGF released by the cells at indicated times (B). Histogram of HB-EGF Western blotting (C); $\mathrm{E}_{2}$ stimulated cells (empty bars) and $\mathrm{E}_{2}$ plus cP stimulated cells (grey bars); mean \pm range from 2 independent experiments.

The extent of apoptosis, determined by flow cytometry, did not show change under the different experimental conditions studied. Thus, the percent of apoptotic cells measured at 48 and $96 \mathrm{~h}$ were: control (including ERnegative) cells, $2.2 \pm 0.1$ and $2.2 \pm 0.3$ respectively; $E_{2}$-treated cells, $2.3 \pm 0.3$ and $2.7 \pm 0.3$, respectively; and $\mathrm{cP}+\mathrm{E}_{2}$-treated cells, $2.0 \pm 0.3$ and $2.4 \pm 0.2$, respectively.

The effect of $2 \mu \mathrm{g} / \mathrm{ml} \mathrm{cP}$ on estradiol-stimulated cell proliferation was compared to that of $100 \mathrm{nM}$ tamoxifen, using the ER-positive CMTC 6 strain. Results in Fig. 3 show that the inhibitory effect of these reagents was similar, limiting estrogen-dependent cell growth. No synergistic effect was observed upon treating cells in the presence of both compounds.

Increased cell proliferation of mammary cells was also observed upon treatment with $5 \mathrm{ng} / \mathrm{ml}$ rh EGF treatment; Fig. 4 shows the cell growth-responses observed in the CMTC 9 strain. The presence of $2 \mu \mathrm{g} / \mathrm{ml} \mathrm{cP}$ in the incubation medium inhibited also EGF-dependent cell proliferation (Fig. 4). Analogous responses were also observed in another four cell strains tested, although the inhibitory action of $\mathrm{cP}$ 


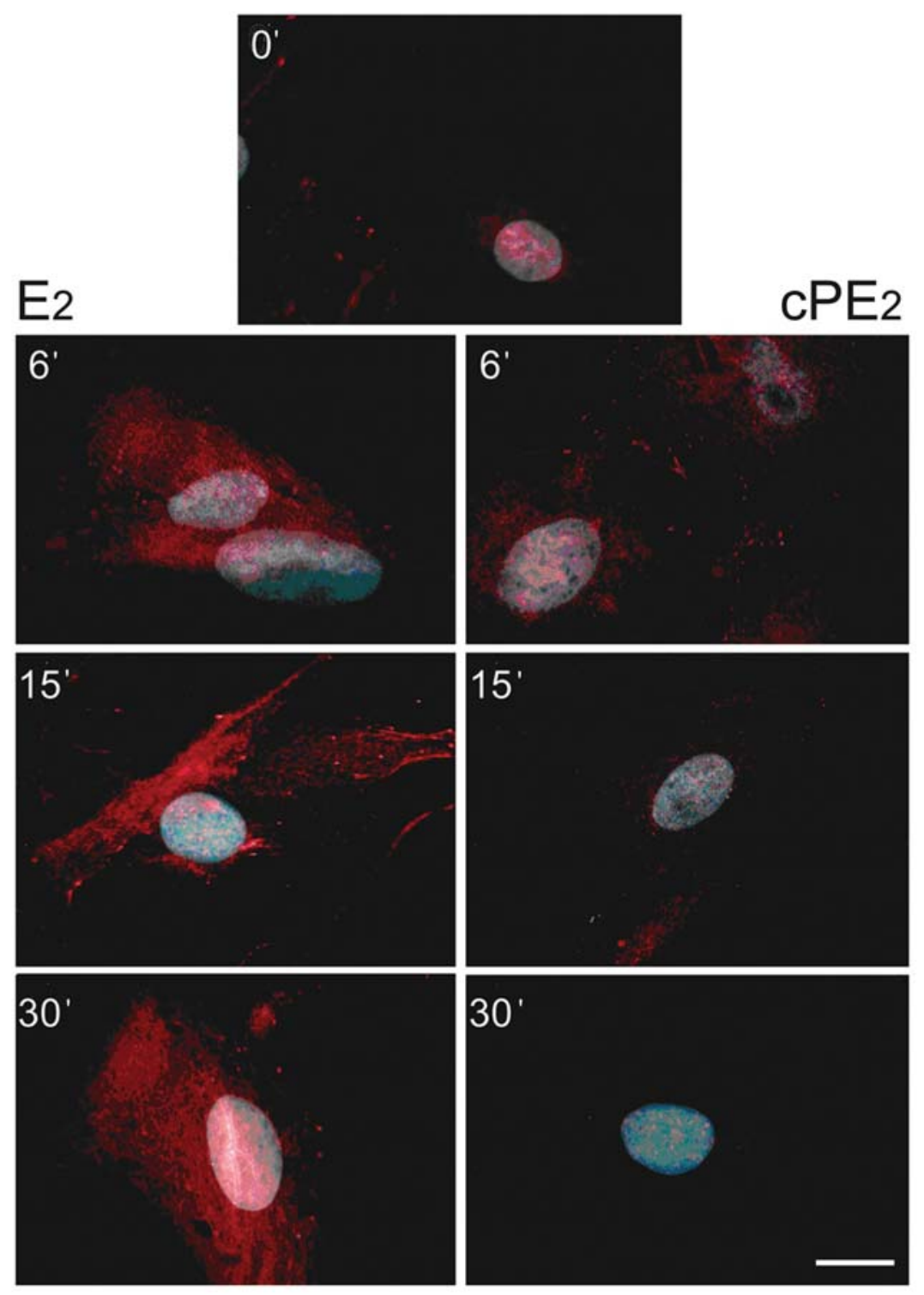

Figure 6. Immunofluorescence for HER2 in CMT14 canine mammary tumor cells stimulated with estradiol and cP. Cells were grown for $48 \mathrm{~h}$ in medium containing 5\% CDCS and stimulated for the indicated times with $2 \mathrm{nM} \mathrm{E}_{2}$ alone $\left(\mathrm{E}_{2}\right)$ or $\mathrm{E}_{2}$ plus $2 \mu \mathrm{g} / \mathrm{ml} \mathrm{cP}\left(\mathrm{cPE}_{2}\right)$. HER2 indirectly-immunostained with Alexa Fluor 594-labeled antibody, nuclei counterstained with Hoechst 33240, as described in Materials and methods. The bar represents $20 \mu \mathrm{m}$.

was not observed in the case of EGF-stimulated CMTC 11 cell proliferation.

In human mammary tumor cells, estradiol activates the EGF pathway through increased synthesis and release of the MMP2, MMP9, followed by the shedding of heparin-binding epidermal growth factor (HB-EGF) from the cell membrane, with the subsequent activation of epidermal growth factor receptor 2 (HER2). Therefore, the effects of estradiol and $\mathrm{cP}$ on the secretion of MMPs were analyzed in the ERpositive CMTC 9 cells (Fig. 5). As shown, estradiol rapidly increased the release of MMP2 and MMP9 by cells, independently of the $\mathrm{cP}$ presence (Fig. 5C). Concomitant with the increased availability of MMPs, a rapid increase in HBEGF shedding was observed (Fig. 5B and C). These estradiol effects were not inhibited by the presence of $\mathrm{cP}$ during cell stimulation.

The relationship between estradiol and EGF action was further analyzed in samples of the ER-positive CMTC 14 cells. Immunofluorescence studies showed that estradiol treatment of cells produced a rapid increase in the immunoreactivity for HER2, which remained for several hours after the stimulus. The presence of $2 \mu \mathrm{g} / \mathrm{ml} \mathrm{cP}$ hindered the estrogen-dependent increase of this receptor (Fig. 6).

We previously showed in human tumor cells that the indirect activation of HER 2 by estradiol initiates complex intracellular signaling pathways leading to the phosphorylation of ERKs (9). This relationship was analyzed in samples of the ER-positive CMCT 9 cells. Fig. 7 shows that after $E_{2}$ stimulation, there was an early increase in the cell levels of phosphorylated ERK1/2, reaching maximal values at $6 \mathrm{~min}$; this cell response decreased significantly when the cells were incubated in the presence of $2 \mu \mathrm{g} / \mathrm{ml} \mathrm{cP}$.

\section{Discussion}

Canine cell lines have been used to study 'ex-vivo' the behavior of hormone-dependent and non-dependent neoplasias $(17,18)$. Isolated tumor cells usually change along 
A

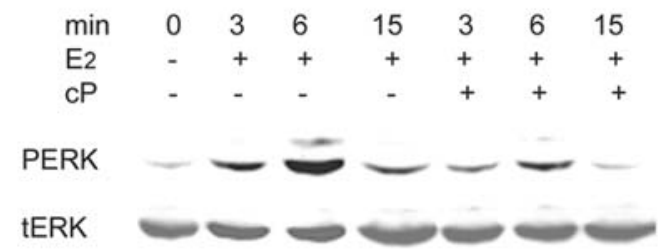

B

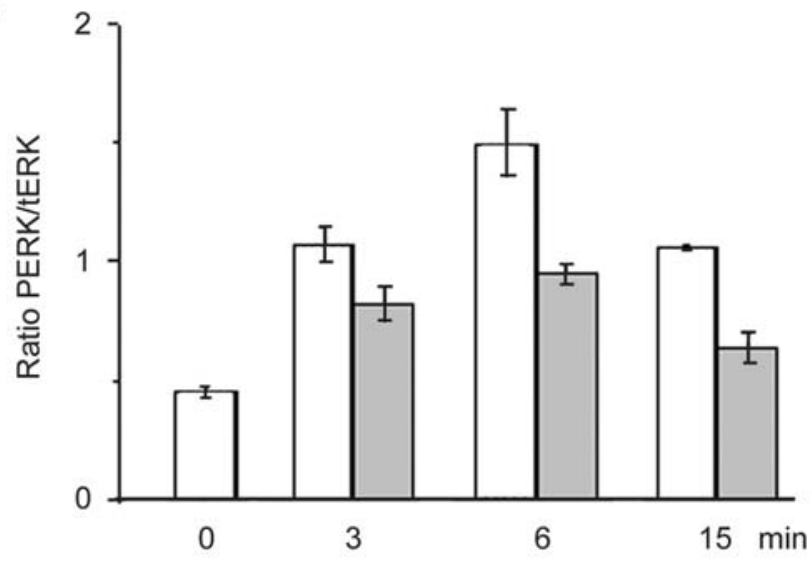

Figure 7. Phosphorylated ERK1/2 in extracts from CMT 9 mammary tumor cells. Cells were treated with $2 \mathrm{nM} \mathrm{E}_{2}$ in the presence or absence of $2 \mu \mathrm{g} / \mathrm{ml}$ $\mathrm{cP}$ for the indicated periods; ERK1/2 phosphorylation assessed by Western blotting as described in Materials and methods (A). The histogram shows the ratio between phosphorylated and total ERK1/2 in cells treated with estradiol alone (empty bars) or in the presence of $\mathrm{cP}$ (grey bars, B). Results are the mean \pm range from 2 independent experiments.

culture due to genotypic and phenotypic instabilities (19); aiming to avoid this and utmost preserving the 'in vivo' conditions, the present studies were done with cells in primary culture, obtained from spontaneous canine mammary tumors.

As expected, tumor samples were heterogeneous considering the histological diagnostic and grade, as well as the clinical staging. Notwithstanding, the cells originating from the primary cultures of these various tumor tissues were predominantly of epithelial character, except one in fourteen strains that showed primarily a myoepithelial nature. ERpositive cells in primary culture expressed the same ER isoforms of the original tumor tissue. Therefore, these primary cultures of ER-positive mammary cells provided another experimental cell model to further analyze the $\mathrm{cP}$ inhibitory action on estrogen-dependent cells.

There is much interest in the effect of compounds that repress or annihilate the estrogen-dependent propagation of mammary cancer cells, in part because many mammary tumors treated with specific ER inhibitors may become resistant to their therapeutic action (4). A cyclic nonapeptide, derived from $\alpha$ fetoprotein, has shown interesting inhibitory effects on the proliferation of estrogen-dependent mammary tumor cells. The cyclized peptide inhibits the estrogenstimulated growth of human, murine or rat mammary tumor cells $(6,7)$ and hinders the growth of human mammary tumors xenoimplanted into severely immuno-deficient
(SCID) mice $(8,20,21)$. The $\mathrm{cP}$ does not show affinity for the estradiol receptors nor $\mathrm{E}_{2}(5,10)$, but interferes with the estrogen-dependent cellular responses mediated by a population of extra nuclear localized ER, considered responsible for most non-genomic actions of estradiol $(22,23)$.

In this study, we show that the $\mathrm{cP}$ also inhibits the growth of ER-positive canine mammary cancer cells in primary culture. These cells significantly increased their growth after treatment with either $2 \mathrm{nM} \mathrm{E}$ or $5 \mathrm{ng} / \mathrm{ml}$ EGF, compared with cells incubated in plain medium. The simultaneous presence of $2 \mu \mathrm{g} / \mathrm{ml} \mathrm{cP}$ in the medium inhibited the proliferative effect of both mitogens, coinciding with our previous observations using ER-positive human mammary tumor cells (9). On the other hand, estradiol exerted no proliferative action, nor $\mathrm{cP}$ inhibited cell growth, in canine mammary cells lacking estradiol receptors, these observations are consistent with those obtained with ER-negative human MDA-MB-231 cells (10). These results support the conclusion that the $\mathrm{cP}$ inhibitory action is exerted on ER-positive cells.

In human breast cancer cells, tamoxifen is a recognized specific ER inhibitor; the compound effectively repressed the estrogen-dependent growth of canine mammary tumor cells. We found that the $\mathrm{cP}$ effect on these cells was of similar extent to that of tamoxifen, although both reagents differ in their cell mechanisms $(20,21)$. No further inhibition of cell growth was attained adding both reagents to cells in culture under these experimental conditions; however, in other cell systems, differing in dosage and incubation periods, the cP and tamoxifen worked cooperatively 'in vivo', inhibiting estrogen-dependent breast cancer growth (21).

We recently reported on the antiproliferative effect of the $\mathrm{cP}$ in ER-positive human mammary tumor cells growing under $E_{2}$ or EGF stimulation (9), showing that the effect of both mitogens is dependent on the activation of the epidermal growth factor receptors at the cell membrane. In cancer cells, EGFR and HER2 appear to be responsible of both the increased proliferation of tumor cells $(3,24,25)$ and the development of resistance to anti-hormone therapy in human patients (4). As mentioned before, studies with human mammary tumor cells demonstrated that estradiol indirectly activates HER2 through the release of matrix metalloproteinases $(26,27)$. The results presented here indicate that this system also operates in canine mammary tumor cells. Thus, estradiol treatment of canine mammary tumor cells developed a time-dependent increase in ERK1/2 phosphorylation, substantiating a crosstalk between the estradiol- and EGF signaling pathways, as previously detailed in human cells $(3,28)$. It has been reported that stimulation of the EGFRs and IGFR is needed for a sustained proliferation of human mammary tumor cells (29). The results presented here reinforce the concept that the activation of the EGFR pathway is necessary for cancer epithelial cell proliferation due to the control of MAPK activity (30). At present, there is optimism in handling some mammary cancers that overexpress the HER2, employing EGFRs tyrosine kinase inhibitors $(31,32)$. Further studies are needed to learn whether the cyclized peptide may be as useful as these inhibitors.

The roles of the estrogen receptors in physiological and pathological conditions are far from being clarified and 
additional strategies to fight estrogen sensitive mammary cancer are needed (3). Among these, the selective inhibition of signaling components under crosstalk control by the ER and HER2, appears most appealing. Since our results confirm that $\mathrm{cP}$ affects this signaling crosstalk, we foresee effective responses of animals carrying spontaneous ER-containing mammary tumors upon treatment with the AFP-derived cyclized peptide, either alone or in combination with tamoxifen, as proposed earlier $(8,20)$.

\section{Acknowledgements}

We are grateful to Professors H.I. Jacobson, J. Bennett and T.T. Andersen (Albany Medical College, NY, USA) for providing the $\mathrm{cP}$ and the scrambled peptide. This study was supported by Fondecyt Chile, Grant 1040881. CGT received a stipend from CONICYT, Chile.

\section{References}

1. Russo IH and Russo J: Role of hormones in mammary cancer initiation and progression. J Mammary Gland Biol Neoplasia 3: 49-61, 1998

2. Russo J, Lareef MH, Balogh G, Guo S and Russo IH: Estrogen and its metabolites are carcinogenic agents in human breas epithelial cells. J Steroid Biochem Mol Biol 87: 1-25, 2003.

3. Arpino G, Weichmann L, Osborne CK and Schiff R: Crosstalk between the estrogen receptor and the HER tyrosine kinase receptor family: molecular mechanism and clinical implications for endocrine therapy resistance. Endocr Rev 29: 217-233, 2008.

4. Shou J, Massrweh S, Osborne CK, Wakeling AE, Ali S, Weiss $\mathrm{H}$ and Schiff R: Mechanisms of tamoxifen resistance: increased estrogen receptor-HER2/neu cross-talk in ER/HER2positive breast cancer. J Natl Cancer Inst 96: 926-935, 2004.

5. Mesfin FB, Andersen TT, Jacobson HI, Zhu SJ and Bennett JA: Development of a synthetic cyclized peptide derived from alphafetoprotein that prevents the growth of human breast cancer. J Pept Res 58: 246-256, 2001

6. DeFreest LA, Mesfin FB, Joseph L, McLeod DJ, Stallmer A, Reddy S, Balulad SS, Jacobson HI, Andersen TT and Bennett JA: Synthethic peptide derived from alpha-fetoprotein that inhibits growth of human breast cancer: investigation of the pharmacophore and synthesis optimization. J Pept Res 63: 409-419, 2004

7. Bennett JA, DeFreest L, Anaka I, Saadati H, Balulad S, Jacobson HI and Andersen TT: AFPep: an anti-breast cancer peptide that is orally active. Breast Cancer Res Treat 98: 133-141, 2006.

8. Parikh RR, Gildener-Leapman N, Narandran A, Lin H-Y, Lemanski N, Bennett JA, Jacobson HJ and Andersen TT: Prevention of N-Methyl-N-Nitrosourea-induced breast cancer by $\alpha$-fetoprotein (AFP)-derived peptide, a peptide derived from the active site of AFP. Clin Cancer Res 11: 8512-8520, 2005.

9. Torres C, Antileo E, Epuñan MJ, Pino AM, Valladares LE and Sierralta WD: A cyclic peptide derived from alpha fetoprotein inhibits the proliferative effects of EGF and estradiol in MCF7 cells. Oncol Rep 19: 1597-1604, 2008.

10. Sierralta WD, Epuñan MJ, Reyes JM, Valladares LE, Andersen TT, Bennett JA, Jacobson HI and Pino AM: A peptide derived from alpha-fetoprotein inhibits the proliferation induced by estradiol in mammary tumor cells in culture. Oncol Rep 19: 229-235, 2008

11. Merlo DF, Rossi L, Pellegrino C, Ceppi M, Cardellino U, Capurro C, Ratto A, Sambucco PL, Sestito V, Tanara G and Bocchini V: Cancer incidence in pet dogs: findings of the animal tumor registry of Genoa, Italy. J Vet Intern Med 22: 976-984, 2008.

12. Flores E and Cattaneo G: Tumores mamarios en caninos domésticos. Epidemiología, criterios de diagnóstico y enfoque terapéutico. (Epidemiology, diagnosis and therapy of mammary tumors in pet dogs). Monogr Med Vet (Chile) 21: 67-78, 2001.
13. Misdorp W: Canine mammary tumours: protective effect of late ovariectomy and stimulating effects of progestins. Vet Q 10: 26-33, 1988 .

14. Queiroga FL, Pérez-Alenza MD, Silvan G, Peña L, Lopes C and Illera JC: Role of steroid hormones and prolactin in canine mammary cancer. J Steroid Biochem Mol Biol 94: 181-187, 2005.

15. Tashbaeva RE, Hwang DN, Song GS, Choi NH, Lee JH, Lyoo YS, Lee SJ, Jung DI, Kim HY and Sur JH: Cellular characterization of multidrug resistance P-glycoprotein, alpha fetoprotein, and neovascular endothelium-associated antigens in canine hepatocellular carcinoma and cirrhotic liver. Vet Pathol 44: 600-606, 2007.

16. Misdorp W: Tumors of the mammary gland. In: Tumors in Domestic Animals. Meuten D (ed). Blackwell, Iowa, pp575606, 2002.

17. Pagnini U, Florio S, Crispino L, Pagnini G, Colangelo D, Rocco D, Pacilio C, Pacilio M, Macaluso M and Giordano A: Direct effect of a gonadotropin-releasing hormone agonist on the growth of canine mammary tumour cells. J Cell Biochem 85: 470-481, 2002.

18. Simon D, Knebel JW, Baumgartner W, Auf der Heide M, Meyer-Linderberg A and Nolte I: In vitro efficacy of chemotherapeutics by $50 \%$ inhibitory concentrations in cell culture of mammary gland tumors obtained from dogs. Am J Vet Res 62: 1825-1830, 2001.

19. Sartin E, Barnes S, Toivio-Kinnucan M, Wright JC and Wolfe LG: Heterogenic properties of clonal cell lines derived from canine mammary carcinomas and senstivity to tamoxifen and doxorubicin. Anticancer Res 13: 229-236, 1993.

20. Bennett JA, Mesfin FB, Andersen TT, Gierthy JF and Jacobson HI: A peptide derived from alpha-fetoprotein prevents the growth of estrogen-dependent human breast cancers sensitive and resistant to tamoxifen. Proc Natl Acad Sci USA 99: 2211-2215, 2002.

21. Andersen TT, Georgekutty J, Defreest LA, Amaratunga G, Narendran A, Lemanski N, Jacobson HI and Bennett JA: An alpha-fetoprotein-derived peptide reduces the uterine hyperplasia and increases the antitumour effect of tamoxifen. Br J Cancer 97: 327-333, 2007

22. Simoncini $T$ and Genazzani AR: Non-genomic actions of sex steroid hormones. Eur J Endocrinol 148: 281-292, 2003.

23. Kelly MJ and Levin ER: Rapid actions of plasma membrane estrogen receptors. Trends Endocrinol Metab 12: 152-156, 2001.

24. Cunliffe HE, Ringnér M, Bilke S, Walker RL, Cheung JM, Chen Y and Meltzer PS: The gene expression response of breast cancer to growth regulators: patterns and correlation with tumor expression profiles. Cancer Res 63: 7158-7166, 2003.

25. Yu D and Hung MC: Role of erbB2 in breast cancer chemosensitivity. Bioessays 22: 673-680, 2000.

26. Razandi M, Pedram A, Park ST and Levin ER: Proximal events in signaling by plasma membrane estrogen receptors. J Biol Chem 278: 2701-2712, 2003.

27. Nilsson UW, Garvin S and Dabrosin C: MMP-2 and MMP-9 activity is regulated by estradiol and tamoxifen in cultured human breast cancer cells. Breast Cancer Res Treat 102: 253-261, 2007.

28. Fox EM, Andrade J and Shupnik MA: Novel actions of estrogen to promote proliferation: integration of cytoplasmic and nuclear pathways. Steroids (In press).

29. Song RXD, Zhang Zh, Chen Y, Bao Y and Santen RJ: Estrogen signaling via a linear pathway involving insulin-like growth factor I receptor, matrix metalloproteinases, and epidermal growth factor receptor to activate mitogen-activated protein kinase in MCF7 breast cancer cells. Endocrinology 148: 4091-4101, 2007.

30. Roberts PJ and Der CJ: Targeting the Raf-MEK-ERK mitogenactivated protein kinase cascade for the treatment of cancer. Oncogene 26: 3291-3310, 2007

31. Konecny GE, Venkatesan N, Yang G, Dering J, Ginther C, Finn R, Rahmeh M, Fejzo MS, Toft D, Jiang SW, Slamon DJ and Podratz KC: Activity of lapatinib, a novel HER2 and EGFR dual kinase inhibitor in human endometrial cancer cells. Br J Cancer 98: 1076-1084, 2008.

32. Bose R and Zhang X: The ErbB kinase domain: structural perspectives into kinase activation and inhibition. Exp Cell Res (In press). 